\title{
5 \\ LAKE GEORGE AND NEW GUINEA
}

Through the activities of companies associated with The Consolidated Gold Fields of South Africa, including a number in which John Agnew was involved flowing from his association with Herbert Hoover, participation was secured in a lead-zinc mine in New South Wales. The Lake George mine was located at Captains Flat, 45 kilometres south-east of Canberra in the Australian Capital Territory and 35 kilometres from the town of Bungendore in New South Wales, from where a railway connection was established in 1939. The deposit was first worked for gold from 1882, with the oxidised ore discovered to be underlain by copper-bearing ore. In 1885 blast furnace treatment was introduced and the deposit was worked by two companies until they amalgamated in 1894 as Lake George United Mining and Smelting Company, reconstructed in 1896 as Lake George Mines. ${ }^{1}$ Mining was undertaken for copper, lead, silver and gold from 1889 to 1899 when the mine was closed.

The redevelopment of Lake George in the 1920s and 1930s was the result of the interaction of a number of the companies established in London, some with connections to Hoover and several in which Agnew played a direct role. The mine came to the attention of a group of London mining engineers and financing companies. It was recognised as a large sulphide deposit of lead and zinc, with a high proportion of pyrite suitable for the production of sulphuric acid and, in turn, superphosphate. Within Australia, Lake George was viewed as the largest-known lead and zinc

1 Chemical Engineering and Mining Review, 5 February 1927, p. 179. 
deposit apart from those at Broken Hill. ${ }^{2}$ The interest came at a time when the United Kingdom Government, after its experiences in World War I, felt a need to assemble technical and financial interests to promote and have access to large base-metals deposits. The challenge of processing complex ores was being tackled at a variety of deposits, not least in Australia, with advances in flotation techniques providing greater confidence that sulphide deposits at depth could be brought into production and be profitable.

In 1925, a London organisation, National Metal \& Chemical Bank, which had been formed in 1918 by an Australian-born banker, Richard Tilden Smith, entered into a contract with Australian mining engineer Leslie Vickery Waterhouse to report upon the mining properties at Lake George. National Metal \& Chemical Bank had an interest in acquiring an involvement in iron ore, coal and non-ferrous metal opportunities, with a specific interest in sulphuric acid and the potential to manufacture superphosphate. ${ }^{3}$ Tilden Smith had an association with Hoover and his investments, including The Burma Corporation, where he was a joint shareholder and director.

The work undertaken by Waterhouse at the abandoned Lake George mine involved dewatering and removing blockages in shafts as well as repairing and replacing equipment. The expenditure was overseen by a local representative, Sir Robert McCheyne Anderson, the grandfather of a future managing director of Renison Goldfields Consolidated in the second half of the 1980s. ${ }^{4}$ National Metal \& Chemical Bank granted an option to another London-based company, National Mining Corporation, to undertake further development work. National Mining Corporation had been established in 1919 as a consortium of United Kingdom mining houses to overcome perceived deficiencies in coordinating capital for the development of base-metal and other mines. The corporation invested broadly in companies, including those that had been associated with Hoover and Agnew, such as Burma Corporation, Santa Gertrudis, Camp Bird and Mexican Corporation. Each of these companies had interests in mining operations that could benefit from the advancement of technology to treat complex ores. On the National Mining Corporation

2 The Times, 26 January 1938.

3 The Times, 16 July 1918.

4 Campbell McCheyne Anderson, who was managing director and chief executive officer of Renison Goldfields Consolidated, 1985-1993. 
board Agnew served as both a director and member of the technical committee, responsible for examining the many operations considered for investment. Burma Corporation, an associated company, was involved in the development of a small experimental plant in England to test the complex ores of the Burma mining operation. Zinc Corporation, of which Govett was chairman, had an involvement in this work for its Broken Hill mine and was a major shareholder in Burma Corporation.

Mining at Lake George recommenced in 1926 when National Mining Corporation took up a sublease from National Metal \& Chemical Bank. According to Tilden Smith, writing from London, National Mining Corporation was described as a 'very powerful' company, taking over development of the mine from August 1926, with this company also having an association with Camp Bird. ${ }^{5}$ A diamond drilling campaign opened up new drives and extended existing ones. An experienced mining engineer, FL Thomas, was sent to the mine on behalf of National Mining Corporation to continue development work, as well as evaluate the reserves of the deposit. In 1926 samples of the sulphide ores containing, lead, zinc, copper and small amounts of silver and gold were sent to England for evaluation. The complex and lower-grade nature of the ore and the depressed state of the metals market led Tilden Smith to observe in 1927 that 'it is absolutely impossible to induce anybody to install a Plant upon the Lake George Leases under conditions anything like so favourable as the sub-lease which I am in a position to secure from the National Mining Corporation Ltd'. ${ }^{6}$

Camp Bird also retained an option on a sublease that it exercised in 1927. As such, both National Mining Corporation and Camp Bird were committed to advancing the technical evaluation of the Lake George ore body. In 1927 the New South Wales chief inspector of mines was invited to report upon the mine's potential, as a precursor to the London investors seeking New South Wales Government support for a railway connection between Bungendore and the mine site. ${ }^{7}$ In 1929, a cooperative business arrangement occurred between Camp Bird and New Consolidated Gold Fields, with Gold Fields gaining representation, through Agnew, on the Camp Bird board. Agnew had been associated with Camp Bird as early as

5 Letter from R Tilden Smith to Sir Robert McC Anderson, 29 July 1926, Butlin Archives, The Australian National University (ANU), Box 67, Folder 2.

6 Letter from R Tilden Smith, Adelaide House, London to Sir Robert McC Anderson, 5 October 1927, Butlin Archives, ANU, Box 67, Folder 2.

7 Chemical Engineering and Mining Review, 5 February 1927, p. 179. 
1914 when Hoover, who was chairman, appointed him to the technical committee of the company. ${ }^{8}$ In turn, New Consolidated Gold Fields offered Camp Bird the opportunity to become involved in any ventures it

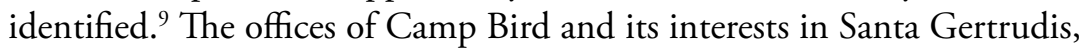
Mexican Corporation, the London committee of the Fresnillo Company and Lake George Metal Corporation were registered at Gold Fields' offices at 49 Moorgate. By this stage Camp Bird held a 75 per cent interest in Lake George Metal Corporation.

A report on the operation observed that the development at Lake George envisaged a plant at the mine that would represent 'the most modern structure in the southern hemisphere', while Thomas's drilling and development efforts had resulted in 3,000 to 4,000 feet of drives being opened, with the potential that reserves could exceed 1 million tons of lead, zinc, copper and silver, with iron as sulphide ore planned to be used for the manufacture of superphosphate. The attraction of the Lake George mine was its large ore reserves of lead and zinc, with the zinc content being of a high quality. It was considered second only to that of Mount Isa in terms of its lead content, while the high pyritic content of the deposit was viewed as a major source of sulphur production, capable of being made into sulphuric acid for the production of superphosphate and with sufficient feedstock for a superphosphate production level to exceed the entire consumption in New South Wales. ${ }^{10}$ Metallurgical research work continued in England. The major drawback to the commencement of operations, apart from market conditions, was that unless a railway connection was built the cost of transport would be prohibitive. ${ }^{11}$

8 Nash, The Life of Herbert Hoover, p. 567.

9 Camp Bird invested broadly and held interests in Santa Gertrudis, Chemical and Metallurgical Corporation, Durango Timber Corporation, Lena Goldfields Notes, Mexican Corporation, Fresnillo Company, Talbot Alluvials, Gold Fields Australian Development Company, as well as Lake George (Chemical Engineering and Mining Review, Mining Handbook of Australia, 1939, p. 106; The Times, 4 September 1929, 15 November 1912, 21 December 1926).

10 Chemical Engineering and Mining Review, 5 May 1928, p. 230; The Australian, 14 January 1939. The Argus in 1897 in a special report compared the Lake George deposit with that of Mount Lyell near Queenstown in Tasmania, with both viewed as 'immense deposits of mixed metals'. In relation to Lake George, the report noted: 'it is safe to say that few mines have such immense reserves of ore, fewer still have the lode so well opened up', with the view that 'the venture is certain to be a success, its probabilities are very great, and its possibilities stupendous' (The Argus, 20 July 1897, p. 7).

11 Chemical Engineering and Mining Review, 5 April 1928. 
Through Agnew's network of contacts and the companies associated with National Mining Corporation, a range of specialist personnel were deployed to Lake George to evaluate the deposit and the complex process required for the separation of metals from the pyritic ores. Hugh Rose, a mining engineer associated with Santa Gertrudis, as well as Thomas Childery Baker, travelled to Captains Flat for the planning of mining and milling activities, including overseeing the construction of a pilot plant. ${ }^{12}$ Baker, an American who was associated with Mexican Corporation, which operated a mine that had to contend with similar issues related to the treatment of sulphide ores, was responsible for the mine's commencement. He became managing director and chairman of the local company. ${ }^{13}$

Sibley B McCluskey, a metallurgical engineer who had consulted to Fresnillo, yet another company in which Gold Fields had a shareholding, was also sent to Lake George while Tom Owen, who had worked on flotation techniques at the Broken Hill mines, was appointed mine manager. Under Owen's supervision, experimental work on the processing of the sulphide ore was undertaken. ${ }^{14}$ Arnold Harris, the mill superintendent at Wiluna, was responsible for ordering the flotation plant at Lake George, while a fellow American, Herbert C Wilkins, who had worked as underground manager at Wiluna, became underground mine superintendent. Yet another American, Charles Prior, the general manager of Wiluna, assisted in the introduction of battery-powered locomotives for underground ore transportation. It was a formidable array of technical experience for the development of what was a complex ore body. The operation of the pilot plant provided 'highly satisfactory recovery of lead and zinc'. ${ }^{15}$ According to one contemporary observer, the mine's plant would involve expenditure of $£ 400,000$ and was expected to be 'the last word in mining and milling'. ${ }^{16}$

12 Chemical Engineering and Mining Review, 5 November 1929, p. 42.

13 The Consolidated Gold Fields of South Africa Limited, 'Report of the Directors and Statement of Accounts, 30th June 1926', University of Melbourne Archives (UMA), Stock Exchange of Melbourne, 1968.0018, Box 67.

14 Reynolds, 'Lake George Mines', p. 342. See also State Library of New South Wales, Captains Flat (Lake George) Mine Records, Accession Code 9607575.

15 The Sydney Morning Herald, 26 January 1931.

16 Chemical Engineering and Mining Review, 5 May 1928, p. 230. 
By 1929 the estimate of ore reserves had increased to be in excess of 2 million tons with the main lode in a channel of 5,000 feet in length and with three main ore shoots expected to 'show persistence in depth both in tenor and width'. ${ }^{17}$ Lake George Metal Corporation was incorporated in 1929 and had as its registered office that of New Consolidated Gold Fields at 49 Moorgate, London. Robert Annan, later to be chairman of Gold Fields, was one of the directors. The shareholders included New Consolidated Gold Fields and The Gold Fields American Development Company. In 1931 Lake George Metal Corporation had the assets of Lake George Mining transferred to the London corporation, with a value of A£748,499 placed on the assets and equipment of Lake George. ${ }^{18}$

Owen, as the manager of Lake George Mines, was well known to Agnew for his technical expertise. Owen worked assiduously during the period from 1924 through to the early 1930s on the metallurgical challenges associated with the Lake George ore body, with separation issues to the forefront. In this regard, he called on the technical expertise not only of his own colleagues within the Gold Fields group but also that of Sir Herbert William Gepp. Gepp, at the time working as a public servant in the Prime Minister's Department, was a noted mining metallurgist with a long career with the Collins House Group companies, including as general manager of Electrolytic Zinc Company of Australasia. ${ }^{19}$ The services of the Council for Scientific and Industrial Research were also used to examine the complex ore body of Lake George. ${ }^{20}$

Market conditions, based on the prevailing price of lead and zinc, meant that the mine remained closed during the early 1930s, with experimental work, including a pilot plant, focusing on the recovery of the pyritic concentrate. Owen made approaches to Broken Hill Associated Smelters regarding the purchase of lead concentrate from Lake George. The oversupply of material from its own mines at Broken Hill meant there was not a ready market for Lake George lead concentrate. ${ }^{21}$ In this context, Gold Fields in London was not prepared to fund the

17 'Santa Gertrudis Co, Ltd', The Mining World, 12 December 1931; Camp Bird, Limited, 'Directors' Report and Statement of Accounts to 30th June 1928', Butlin Archives, ANU, 67/12.

18 Letter from SC Leaman, Secretary of Lake George Metal Corporation to the Secretary of Lake George Mines Ltd, 15 January 1931, Butlin Archives, ANU, 67, 205-210.

19 Kennedy, 'Gepp, Sir Herbert William (Bert) (1877-1954)'.

20 Letter from G Lightfoot, Secretary, Council for Scientific and Industrial Research to HW Gepp, Development Branch, Prime Minister's Department, 19 August 1930, National Archives of Australia (NAA), A786,064/7.

21 Letter from Colin Fraser to TM Owen, 26 February 1932, Butlin Archives, ANU, 67/171. 
start of mining operations. Owen was drawn into assisting New Consolidated Gold Fields with its other mining ventures in Australia in the early 1930s, particularly at Wiluna, where he spent an extended period undertaking detailed technical analysis of the treatment plant, in particular the appropriate flotation process for the refractory ores, while work also continued on the recovery of elemental sulphur from pyrite, which comprised 32 per cent of the Lake George ore. ${ }^{22}$ For a period, Owen also assisted Oroville Dredging with its aerial survey work in New Guinea, reflecting the interconnections of the companies and personnel in which Gold Fields had interests. ${ }^{23}$ Work in assisting the other group companies in Australia also included the Lake George metallurgist, Sibley McCluskey. He spent time at Wiluna assisting the mine manager, Herbert Vail, in the design of the flotation section of the Wiluna mine, as well as that at Lake View and Star. ${ }^{24}$ This experience proved invaluable in the flotation experimentation conducted at Lake George.

In 1934, FW Baker, chairman of the London company, visited New South Wales to discuss matters relating to the resumption of mining operations, including holding discussions with the New South Wales Government about a railway connection between the mine and Bungendore. ${ }^{25}$ In 1937, Lake George Mining Corporation was formed, taking over the shares of Lake George Metal Corporation, which had been placed into liquidation. Discussions occurred with the New South Wales Government for the construction of a railway link. The New South Wales Government agreed to support the construction of the railway line and in return Lake George Mining Corporation agreed to spend A£600,000 on equipping the property, storage and loading facilities at Port Kembla, and construction of a transmission line and loading facilities at Bungendore. ${ }^{26}$ In 1937, with higher metal prices, steps were taken to begin mining operations and contracts were placed for mining equipment.

22 Chemical Engineering and Mining Review, 8 June 1936, pp. 320-321.

23 Chemical Engineering and Mining Review, 8 May 1935, p. 287.

24 Letter from HE Vail to L Thomas Esq, Lake George Mine, 10 September 1929, Butlin Archives, ANU 67/12; Mainwaring, Riches Beneath the Flat, pp. 19, 21, 24.

25 Lake George Mining Corporation Limited, 'Report for the Directors, 31st December, 1934', Butlin Archives, ANU, 67/12. Baker was also the chairman of Camp Bird and Santa Gertrudis.

26 Chemical Engineering and Mining Review, 15 December 1937, p. 91. 
Mining operations commenced in 1937 and milling in January 1939. A£676,000 had been invested in plant and equipment to enable the mine to open, with electrical power generated by a transmission line from the Burrinjuck hydro-electric scheme, shafts sunk and commencement of construction of housing in the nearby township of Captains Flat. The operation gained from the input of Harris, who had worked as a superintendent of the Wiluna gold mine, while the extensive technical resources of various arms of the Gold Fields group had been drawn upon. New Consolidated Gold Fields provided the technical support of its mechanical engineering department. Gold Fields American Development Company assisted, including for the purchase of mining and processing equipment, while Consolidated Gold Fields of South Africa provided input in relation to drilling and reserve evaluation. ${ }^{27}$

Mining was conducted at Lake George during its economic life from 1937 to 1962 . The treatment plant incorporated crushing, grinding and flotation, utilising four separate sections for copper, lead, zinc and pyrite. Concentrate was sent by rail to Port Kembla from Bungendore. The mine produced zinc and lead, with smaller quantities of copper, silver and gold, and sulphur from the pyritic ores. In the 1950s the workforce stood at over 500 employees and the company had established housing to attract employees, including 180 homes as well as quarters for single men. The Captains Flat township, located in the valley below the mine, experienced a resurgence with the mine's recommencement. The company supported sporting and cultural activities, and purchased the local theatre and later redeveloped it, installing one of the first cinemascope screens outside Sydney. The township had other facilities including a bank, post office, hospital, police station and courthouse.

After the long gestation before operations began, the mine experienced numerous problems in its initial years. During its first two years the operation was adversely affected by an extended strike at a smelting customer in the United States, the scarcity of shipping and higher freight and insurance costs. In the year to 30 June 1940 an operating loss of $\mathrm{GB} £ 72,523$ was recorded, with a smaller loss the following year. The first

27 The Lake George archival material held at the Butlin Archives, ANU, contains a voluminous collection of technical correspondence from 1938 to 1961 reflecting the breadth and extent of the technical assistance provided by member companies of the Gold Fields group. 
annual profit was recorded in $1942 .{ }^{28}$ As the company's operational issues were being addressed it was faced 'with a new set of problems ... beyond its control' - not least the onset of World War II. ${ }^{29}$

The war imposed challenges related mainly to the availability of labour and the cost of obtaining shipping and war insurance, as well as the limited market for lead concentrate, for which the United States was the only available market. Zinc concentrate, which was being supplied to the British Ministry of Supply, went into oversupply. Requests for higher prices or a premium for zinc concentrate were made but to no avail. Representations were made to both the New South Wales and Commonwealth governments, the latter for relief on lead prices or the potential payment of a lead bonus. These were not forthcoming and the mine was in 'imminent danger of closing down', leading to representations by the New South Wales Branch of the Australian Workers' Union to the prime minister to protect the 'valuable State assets now threatened by extinction'. ${ }^{30}$ The New South Wales Government provided temporary relief on the cost of hydro-electric power, as well on rail freight charges from October 1940 to June 1942.

The wartime circumstances imposed numerous challenges on the mine and its management. Thomas Baker, as managing director, was active in not only canvassing financial assistance but in multiple requests for mining equipment, financial support to build cottages to attract married men, as well as suitable boots and clothing to deal with the acid nature of the mine water. ${ }^{31}$ Equipment supplies were secured that allowed a copper production unit to commence in early 1942, enabling the copper in lead being sent to the United States to be extracted at the mine.

28 Lake George earned a profit of $\mathrm{GB} £ 4,000$ for the 1942 financial year, the first in the history of the company, associated with an increase in copper recovery and a doubling of pyrite production when a new market was found for about half of the pyrite production (Chemical Engineering and Mining Review, 10 June 1943, p. 265; West Australian Mining and Commercial Review, vol. 7, no. 5, July 1942, p. 20; 'Lake George Lead Concentrate and Relation to Dollar Exchange and Petrol Purchases', NAA, A461, S373/1/2, p. 90).

29 Letter from the managing director, Lake George Mines Limited to PC Spender, Commonwealth treasurer, 22 July 1940, NAA, A461, S373/1/2.

30 Colonial Treasurer, New South Wales, Sydney, 8 June 1942, Lake George Mines, NAA, A461, S373/1/2; letter from AWU New South Wales Branch to the Prime Minister, 27 August 1930, NAA, A461, S373/1/2.

31 NAA, A1146, N6/4 Part 1. 
In 1942, a 'calamity with the tailings dam' necessitated an urgent request to the Commonwealth Government for piping to supply fresh water to the mine and the townsite. ${ }^{32}$ The support sought of the Commonwealth Government extended to representations to the State Department of the United States to assist Mrs Baker, who had travelled to California before the outbreak of the war, to return to New South Wales to be with her husband. The concern by a Commonwealth Government official with responsibility for the oversight of minerals production was that Baker was 'becoming restive', with a fear that 'his services so important to production will be lost either through break-down or his return to U.S.A'. ${ }^{33}$ His possible departure could be averted if arrangements were made for his wife to rejoin him.

The financial assistance from the New South Wales Government was able to be suspended one month earlier than planned. In 1946 an operating profit of $\mathrm{GB} £ 38,567$ was generated, accumulated losses written-off and the repayment of a loan of $\mathrm{GB} £ 726,777$ made to the London corporation. ${ }^{34}$ The mining and processing operations, however, continued to experience challenging conditions after World War II, including increased costs and labour issues. Apart from a 40 per cent increase in rail freight charges in 1947 and other increases, wages rose sharply, while labour turnover and industrial disruption were endemic. In 1948, the average number of men on the payroll was 403 but only an average of 346 attended work at any one time during the year. Turnover of workers was 147 per cent, with the effect that about'a quarter of the mine employees ... leave before they have time to become familiar with or skilled in any operation'. ${ }^{35}$ Wages had increased an average of 10 to 18 per cent and if the lead bonus was included, by 36 to 44 per cent; a level nearly three-quarters higher in 1948 than in 1939.

The mine's performance also suffered from the vagaries of metal prices and, at times, a fractious industrial relations situation. Industrial disputes and strikes were frequent. In 1942, 250 workers went on strike when water was not available in the change rooms. In that year the company recorded a loss. In August 1947 'a go-slow policy' was followed by strike action in 1948 for an increase in the lead bonus.

32 Telegram, 13 July 1942, NAA, A1146, N6/4, Part 1.

33 Letter from Secretary, Department of Supply and Shipping to Secretary, Department of External Affairs Canberra, 2/12/1942, NAA, A1146, N6/4, Part 1.

34 The Times, 14 November 1947.

35 Chemical Engineering and Mining Review, 10 May 1949, p. 305. 


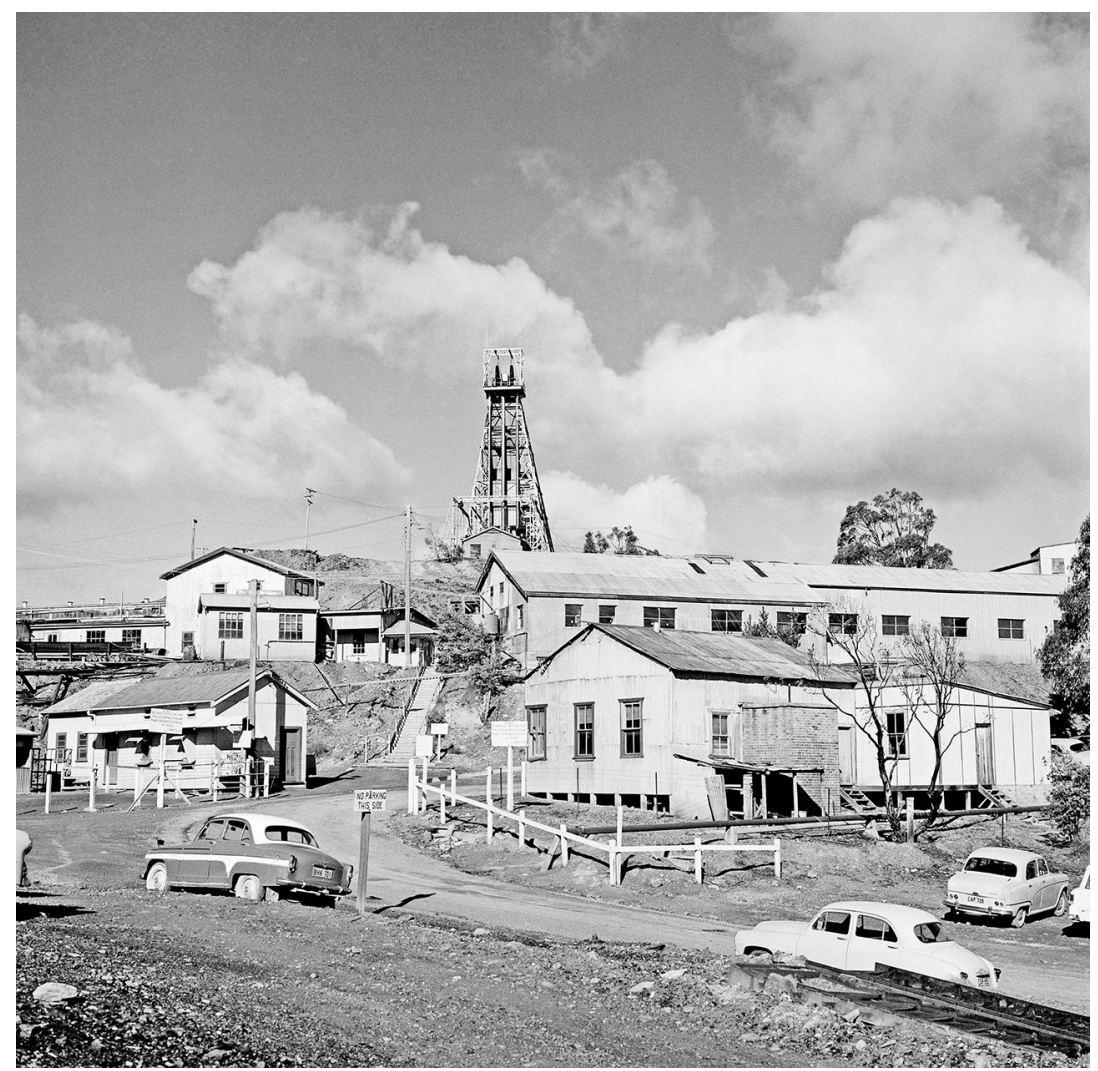

Figure 19. Lake George mining and processing operations, Captains Flat, New South Wales.

Source: NAA, A1200, L39590.

In the following financial year, only 67 days of production were recorded with a strike that ended in May 1949 after an initial 'go-slow' approach in September 1948, followed by a national coal strike that caused a further suspension of operations. Despite being on strike, most of the workers still attended the Captains Flat hotel for the general manager's Christmas drinks. ${ }^{36} \mathrm{~A}$ loss that year was only averted by a considerable amount of concentrate at the mine that was able to be processed. ${ }^{37}$

36 Pryke, Van Straaten and Walker, Boom to Bust-And Back Again, pp. 48-49.

37 Chemical Engineering and Mining Review, 10 July 1950, pp. 410-411. 


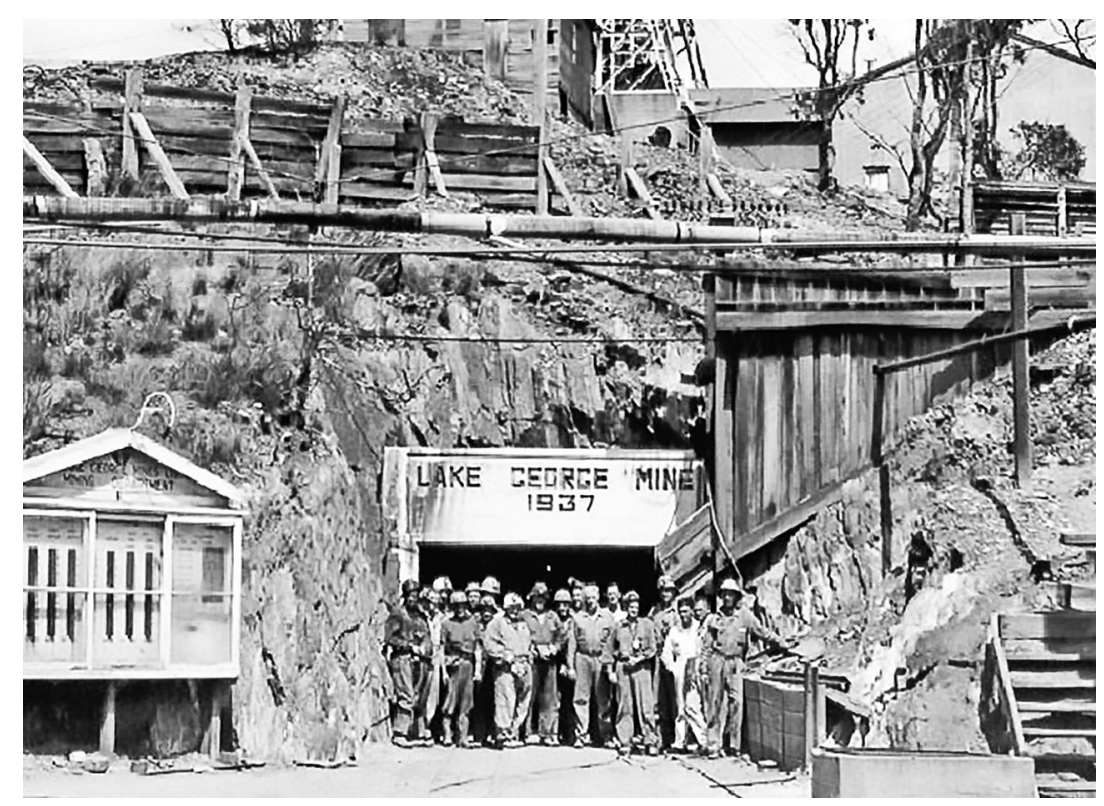

Figure 20. Final shift at time of closure of Lake George mine, 1962.

Source: Captains Flat Community Association.

In 1954 and 1955 a lock-out occurred, operations were suspended and 300 workers stood down from June 1954 to February 1955. Mine management had to contend with an internecine conflict between two unions-the Miners' Federation and the Australian Workers' Union. As information on signage at what are now the remnants of the mine site infrastructure conveys, separate change room facilities were provided to the different unions. In the 1956 financial year, mine operations were suspended yet again, resulting in a loss for the year, following industrial stoppages relating to the company's right to deepen the shaft by using outside contractors. ${ }^{38}$ In 1958, following further industrial disputation, Tom Owen, by then Australian chairman of Lake George Mines, advised the London-based chairman of Lake George Mining Corporation: 'If the men's representatives were deliberately trying to force us to close the Mine you would expect them to adopt the tactics they are following. ${ }^{39}$

38 Chemical Engineering and Mining Review, 10 July 1956, p. 325.

39 Letter from TM Owen to Hon RMP Preston, Chairman, Lake George Mining Corporation Ltd, 9 September, 1958, Butlin Archives, ANU, 80, 9. 
Despite recording profits in the late 1940s and early 1950s, by the late 1950s the challenges of a maturing ore body and weaker prices had become apparent. ${ }^{40} \mathrm{~A}$ world-wide slump in metal prices, including zinc and copper, and increasing operating costs resulted in a loss in 1958. In the same year, it was viewed that Captains Flat was 'threatened with extinction' due to the decision of the United States Government to restrict imports of lead and zinc. ${ }^{41}$

The major hope for the mine's continuation was the identification of additional ore through deeper exploration drilling, conducted to a depth of 3,000 feet. In 1960 the board of directors was informed that the exploration program at both surface and underground had 'failed to disclose any economic extensions to existing ore bodies or to reveal any new deposits. ${ }^{42}$ In 1960, Owen wrote to the London-based chairman of the company in relation to various matters in the event that the mine and company had to be closed or liquidated, given that the operation had nearly exhausted the availability of profitable ore. Owen raised several challenges facing the company in terms of its continued, if limited operation. These included the risks to continuing mining operations due to the 'unpredictable industrial risk' and, in particular, 'the supply and behaviour of the employees, particularly of the A.W.U. [Australian Workers' Union] men whose membership at Captain's Flat continues as a solid core of admitted Communists' ${ }^{43}$ The risk of pollution to the Molonglo River was highlighted; it was not uncommon for the large tailings dumps containing pyrite to break their banks and spill into the river. The company was also facing claims for damages from local landholders associated with the adverse effects of mining activity on agricultural land in the vicinity of the mine. ${ }^{44}$ Owen wrote, in a near exasperated tone:

40 Operating profits in British pounds sterling for the London Corporation were: 1948, $£ 291,799$; 1949, £324,843; 1950, £498,813; 1951, £892,290; 1952, £1,084,350 (Chemical Engineering and Mining Review, 11 February 1952, p. 188).

41 Chemical Engineering and Mining Review, 15 November 1958, p. 65.

42 Lake George Mines Pty Ltd, 14 September 1960, Board of Directors, p. 4, Butlin Archives, ANU, 80, 9.

43 Letter from TM Owen to Hon RMP Preston, Chairman, Lake George Mining Corporation Ltd, 27 February 1960, p. 2, Butlin Archives, ANU, 80, 10. Preston had been appointed a director of Consolidated Gold Fields of South Africa in 1946.

44 ibid., p. 3. 
The position facing the future of Lake George being so serious, it would be a great relief to me-and I feel to all of us - if it were possible for you to visit us here in the near future to familiarise yourself with the more important problems and thus assist us in dealing with them. ${ }^{45}$

The approach of the London board was to accept the reality of the mine's closure, allow production to decline while seeking to avoid antagonising the unions and reach a settlement with landowners before the company went into liquidation. The London chairman raised the question of whether the company could take advantage of the location and infrastructure at Captains Flat for the establishment of some other industry. He wrote to Owen:

The Board in London feel that this matter should be attacked now, and that you should let it be widely known that you are effectively engaging in looking for some industry to take the place of the Mine, and thus incidentally counter the propaganda of the Communists. ${ }^{46}$

In a handwritten addendum to his letter to Owen, the chairman added: 'We all do indeed sympathise with you ... in your troubles and anxieties, and regret that there is so little we can do to help'. ${ }^{47}$ In effect, closure was the accepted outcome with efforts directed to ensuring the maximum level of funds be returned to London shareholders. A capital return of two shillings per share occurred and a $A £ 300,000$ interest-free loan was remitted to Lake George Mining Corporation in December 1962.48 In March 1962 the mine closed. During the period 1939 to 1962 it had milled over 4 million tons of ore and produced 143,600 tons of copper, 234,600 tons of lead, 386,560 tons of zinc, 346,340 tons of pyrite, 90,057 ounces of gold and 4,963,440 ounces of silver. ${ }^{49}$ The mine's equipment was sold, raising $A £ 400,000$ in 1963 and in 1964 the London company was placed into voluntary liquidation.

Concurrent with its investments in Australian gold companies, Gold Fields pursued gold interests in the Territory of New Guinea, where Australian civil administration had been established through a League of Nations trusteeship in 1921 after the cessation of German occupation.

45 ibid., p. 7.

46 Letter from Dick Preston to Tom M Owen, 14 March 1980, p. 2, Butlin Archives, ANU, 80, 10.

47 ibid.

48 Lake George Mines Pty Limited, 'Meeting 14th Day of December 1960', Butlin Archives, ANU, $80,10$.

49 Reynolds, 'Lake George Mines', p. 345. 
Prospecting and minor gold mining activity had been undertaken by Australians in New Guinea since the early 1920s. ${ }^{50}$ In Morobe district on the north coast of the country the topography is noted for its rugged and mountainous terrain, with a number of valleys including the Wau and Bulolo. The Edie, Koranga and Wau Creeks flow into the Bulolo River, which courses down a wide gorge. The alluvial gold deposits in Morobe district near the Bulolo River had come to the attention of Cecil John Levien, a district officer with the Australian administration..$^{51}$ After resigning from colonial administration, Levien and colleagues established a company, Guinea Gold No Liability, which was listed on the Adelaide stock exchange in 1926. It established a small alluvial plant that recovered 'rich gold including specimens nuggets [sic] of coarse gold' through ground-sluicing operations. ${ }^{52}$ The major issue facing this small-scale mining operation was access to the site, which, while only 48 kilometres from the coast, required an eight-day trek to the coast due to the difficult terrain. The company purchased two planes to transport food, merchandise and passengers. The company's chief pilot, Flight Lieutenant Mustar, was given the responsibility to procure larger, all-metal aircraft, capable of transporting heavier equipment to site..$^{53}$ The company transferred its aviation activities to a separate company, which would form the basis of the New Guinea national carrier, as well as the foundation of air travel in Papua and New Guinea.

Despite the potential of the area, the financial situation of Guinea Gold, the scale of the investment to develop the area and initial disappointment with the resource potential, led the directors to withdraw from future activities, a decision that was only negated by soliciting assistance from other sources. In 1928, the mining engineer who had responsibility for establishing Mount Isa Mines, William Henry Corbould, travelled to New Guinea on behalf of Leslie Urquhart, then chairman of Mount Isa Mines. ${ }^{54}$ Urquhart had an interest in fostering the development of alluvial deposits in New Guinea. Corbould took options over leases and water rights in the upper Bulolo and Edie Creek areas. The Elleyou Goldfields

50 The discovery and development of the Morobe goldfields is told in Rhys, High Lights and Flights in New Guinea, p. 183. For other accounts of gold mining in Morobe district, see Nelson, Black, White and Gold; Idriess, Gold-Dust and Ashes; Lett, Papuan Gold.

51 Healy, 'Levien, Cecil John (1874-1932)'.

52 Guinea Gold No Liability, 'The Shareholders of Guinea Gold No Liability 7th November 1927', UMA, Stock Exchange of Melbourne, 1968.0018, Box 119.

53 Langmore, 'Mustar, Ernest Andrew (1893-1971)'.

54 Blainey, The Rush that Never Ended, pp. 326 and 329; see also Kennedy, 'Corbould, William Henry (1866-1949)'. 
Corporation was formed in 1928 to undertake further evaluation in New Guinea. ${ }^{55}$ This included a survey for a potential railway to transport the gold recovered to the coast. Given the rugged terrain, this was not practicable and aircraft transportation formed the basis of the development of the area. Urquhart maintained a positive assessment of the gold potential of the area, observing in 1929:

Since the opening of the Rand, no goldfield exhibiting the potentialities of New Guinea has been discovered, and if the present work in ore development in depth is attended with that success already attained in our work on the numerous valuable gold veins so far found, we shall be fully justified in claiming that in New Guinea we have, under the British flag, a new goldfield of the greatest importance. ${ }^{56}$

Meanwhile in 1928, Placer Development, a British Columbia company, sent a mining engineer and his assistant to New Guinea to evaluate the lower Bulolo leases of Guinea Gold. Consolidated Gold Fields of South Africa had a connection with alluvial gold mining that began when it took interests in the Oroville and Yuba gold-dredging companies in California as early as 1909, and then a prospecting partnership with Placer Development in the 1920s. ${ }^{57}$ Placer's evaluation determined the existence of payable gold leases that extended into areas held by Guinea Gold. Some of the Guinea Gold leases were sold to Placer for $£ 50,000$, while a new Canadian incorporated company, Bulolo Gold Dredging, was formed in 1930 to work the leases. Consolidated Gold Fields of South Africa and Gold Fields American Development Company subscribed to 200,000 of 467,000 shares available of the total 800,000 shares for the company and thereby contributed a large part of the capital necessary for development work to begin. In addition, the companies acquired 10,000 of 30,000 Placer shares, and held an option over the remaining 20,000 shares, which would become available 12 months after the start of dredging operations. ${ }^{58}$ As such, Gold Fields, established a major position in this part of the Bulolo fields. ${ }^{59}$ Placer, in turn, held a 22 per cent in Bulolo Gold Dredging.

55 The Times, 10 December 1928 and Kennedy, Mining Tsar, pp. 257 and 258.

56 The Times, 13 November 1929.

57 Consolidated Gold Fields of South Africa, The Gold Fields 1887-1937, p. 97.

58 Placer Development Limited, 'Bulolo Gold Dredging Limited Flotation, 29/4/30', UMA, Stock Exchange of Melbourne, 1968.0018, Box 256; Guinea Gold No Liability, 'Notice to Shareholders, 13th August 1930', UMA, Stock Exchange of Melbourne, 1968.0018, Box 119; see also Consolidated Gold Fields of South Africa, The Gold Fields 1887-1937, pp. 113-114.

59 In 1954, Consolidated Gold Fields of South Africa disposed of its interest in Oroville Dredging and Bulolo Gold Dredging (The Times, 10 November 1954). 
Urquhart's company had also secured options over leases from Guinea Gold, including those on the upper Bulolo and Edie Creek, through a consideration of shares in a company it established in London for the purpose of conducting sluicing and reefing operations in New Guinea. ${ }^{60}$ In 1929, the London-based company, Elleyou Development Corporation, exercised its option and established a new company, New Guinea Goldfields, listed on the Sydney stock exchange, with some of its shares distributed to shareholders of Guinea Gold. This enabled the various interests in the Edie Creek area to be amalgamated. Gold Fields also established a shareholding in this company. The original prospecting company, Guinea Gold, continued to exist, although its main interest was in shareholdings in New Guinea Goldfields and Bulolo Gold Dredging. ${ }^{61}$

Dredging was adopted to mine the alluvial deposits of the Bulolo River, downstream from Wau. Transporting dredging equipment to the remote and mountainous location was challenging. In 1931, the commercial airlift of mining equipment began with the first two of eight 2,000-ton dredges, as well as all other mining equipment, transported to site. Two Junker 31 aircraft flew from Lae on their maiden flight in April 1931, 'glistening in the sun like a huge dragon-fly'. ${ }^{62}$ The aircraft subsequently carried in thousands of tons of machinery, all of which had to be custom made to fit inside the aircraft. In 1932, Placer issued additional shares to fund its operations. Oroville Dredging Company acquired 55,000 of the 65,000 shares. Oroville Dredging was considered one of the world's most successful gold-dredging companies and was involved with Placer in gold-dredging activities in Colombia. ${ }^{63}$ Consolidated Gold Fields of South Africa had a substantial interest in Oroville Dredging and, as such, gained a further involvement in the Bulolo fields, both as a shareholder in Placer and provider of technical assistance.

60 Guinea Gold No Liability, 11 July 1928, UMA, Stock Exchange of Melbourne, 1968.0018, Box 119 .

61 State Library of South Australia, BRD65/1/1, Guinea Gold No Liability and PRG 429 Lapthorne, WPA.

62 Rhys, High Lights and Flights in New Guinea, pp. 186-187.

63 Placer Development Limited, 'Bulolo Gold Dredging Limited, Memorandum to Shareholders, February 29th, 1932', p. 1, UMA, Stock Exchange of Melbourne, 1968.0018, Box 49. 


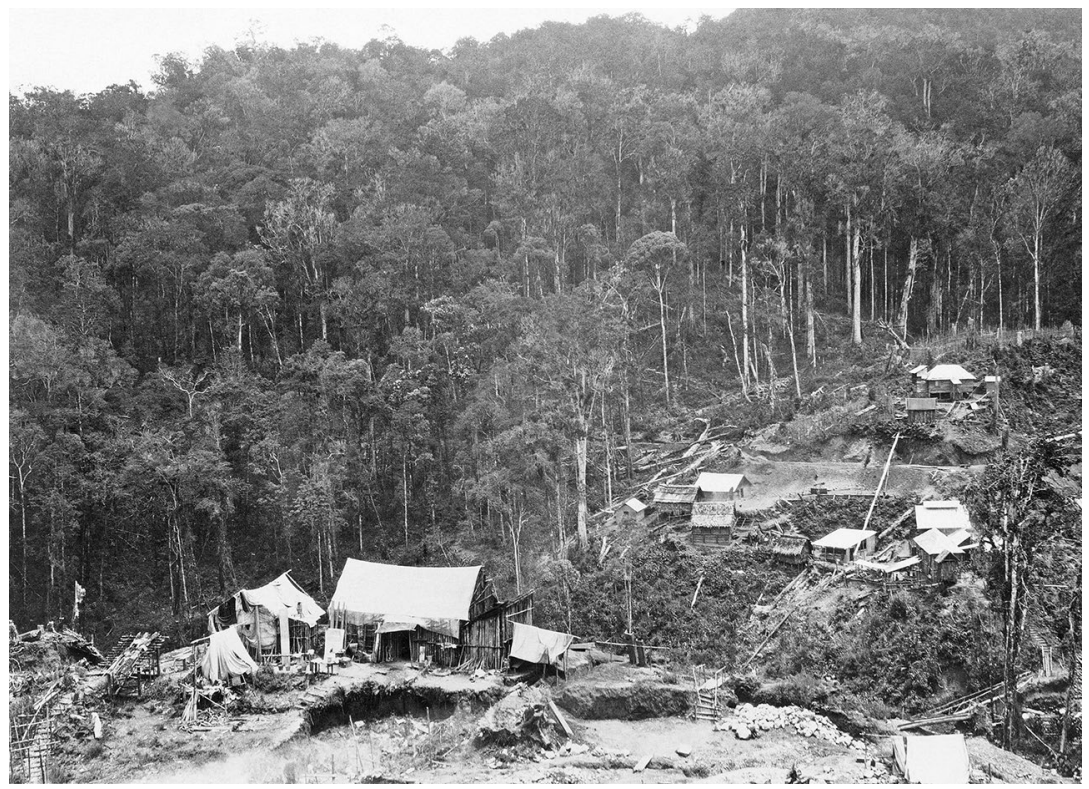

Figure 21. Alluvial gold mining, Edie Creek, Morobe district, Territory of New Guinea.

Source: NAA, A6510, 2310.

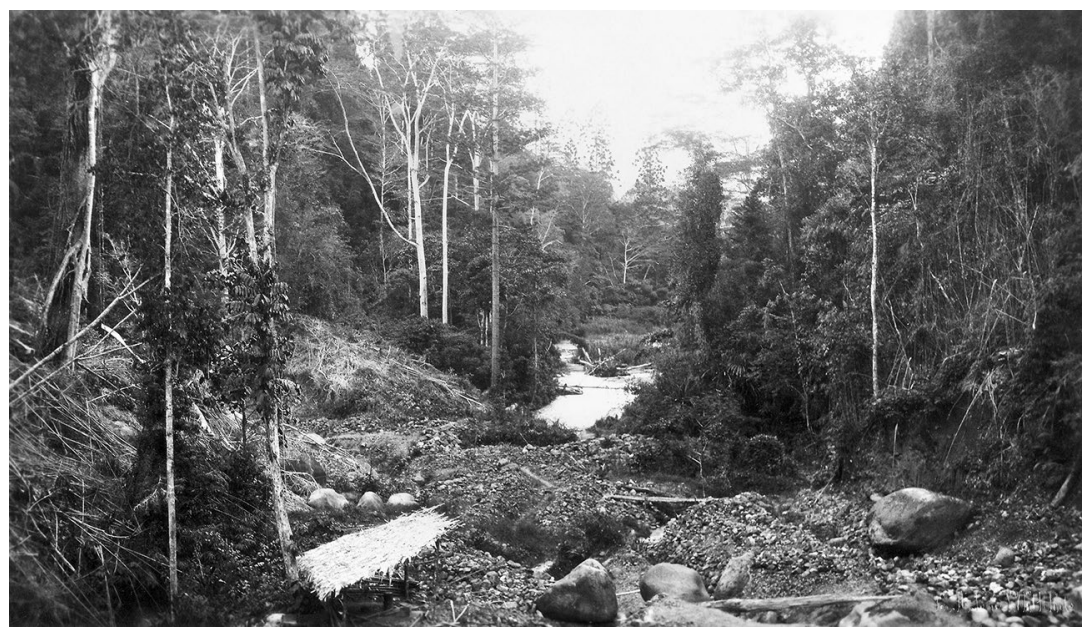

Figure 22. Location for mining operations undertaken by New Guinea Goldfields at the junction of Bulolo River and Koranga Creek, Morobe district, Territory of New Guinea.

Source: NAA, A6510, 2306. 


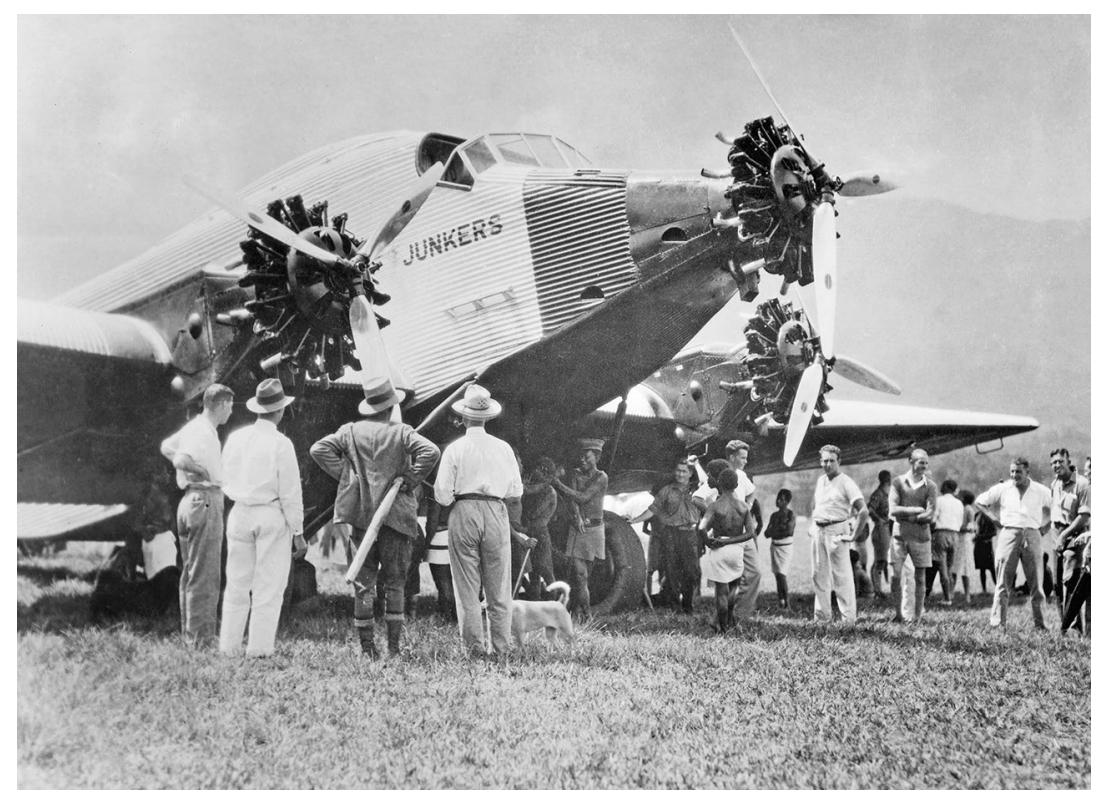

Figure 23. Junker aircraft used for transportation of equipment into Morobe district, Territory of New Guinea.

Source: NAA, A6510, 760544.

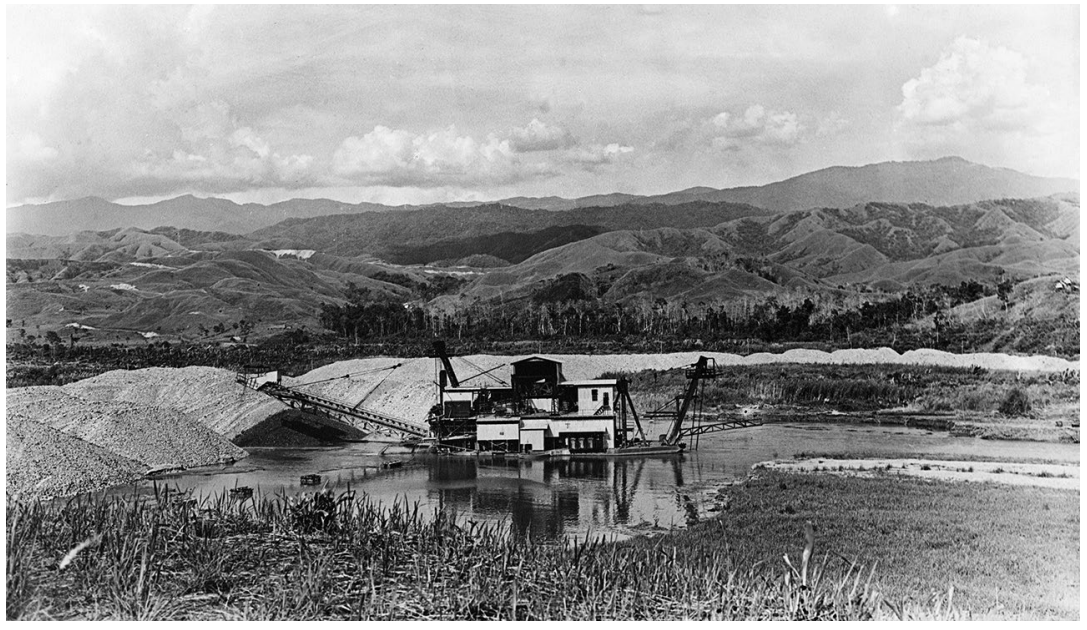

Figure 24. Bulolo gold dredge, number 3, Morobe district, Territory of New Guinea.

Source: SLSA, B71530. 
Bulolo was referred to as the 'most profitable alluvial gold-mining operation ever undertaken'. ${ }^{64}$ From 1932 to 1940, 1,027,263 ounces (32 tons) of gold and 456,921 ounces (14 tons) of silver were recovered. ${ }^{65}$ Operations ceased in January 1942 as a result of Japanese bombing attacks that destroyed three of the company's aircraft at the Bulolo aerodrome as well as workshops and storehouses, while the Australian administration's 'scorched earth' policy led to the rendering of other equipment, including dredges, inoperable. Production recommenced after the war and Bulolo was eventually amalgamated into Placer Development in 1966, after dredging operations had ceased in 1965. Sluicing operations continued.

New Guinea Goldfields developed its deposits using an alluvial mining approach as well as shaft mining of reefs at depth. A mill was constructed at Edie Creek in 1935 to support the workings, with a workforce of over 130 expatriate employees and more than 1,000 indigenous employees. ${ }^{66}$ In 1933, a profit of $A £ 215,186$ was recorded and an initial dividend paid. Compared with the experience of Bulolo Dredging, New Guinea Goldfields' performance was modest and it struggled financially. By 1936 the richer sections of the alluvial fields had been exhausted and by 1941 the underground mining activities were loss-making, with remnant alluvial mining and tribute mining contributing to a modest profit. ${ }^{67}$ In June 1937, Julius Kruttschnitt was appointed chairman. Kruttschnitt was at the time both chairman and general manager of Mount Isa Mines. He later played a role as chairman of Commonwealth Mining Investments (Australia), the first investment made by Consolidated Gold Fields (Australia) after it was formed in 1960.

As such, Gold Fields established a presence in gold mining activities in New Guinea through a shareholding in two of the main companies involved in Morobe district. The involvement in Papua and New Guinea was reconsidered in the 1960s and again in the early 1980s when Renison Goldfields Consolidated acquired New Guinea Goldfields in conjunction with its London parent, while a further association with Placer Pacific led to the development of the major Porgera gold deposit in the country in 1990 .

64 Cartwright, Gold Paved the Way, p. 206; see also Waterhouse, Not a Poor Man's Field.

65 Bulolo Gold Dredging, Limited, 'Report and Statement of Accounts for the Year Ended 31st May, 1940', UMA, Stock Exchange of Melbourne, 1968.0018, Box 48.

66 UMA, Stock Exchange of Melbourne, 1968.0018, Box 209; Hore-Lacy, Broken Hill to Mount Isa, pp. 212-213.

67 Chemical Engineering and Mining Review, 9 March 1936, p. 205 and 10 January 1942, p. 163. 
Despite the expansive approach that the Gold Fields group had taken in Australia and its territorial possession in New Guinea, in the late 1950s the Australian interests of the British group were restricted to Lake View and Star and Mount Ida. Gold Fields Australian Development Company, despite its promise, failed to provide a base for Gold Fields' ongoing involvement in Australia. It continued to exist, in name only, until December 1967 when, after evaluation of its base-metal exploration opportunities, the company was liquidated. ${ }^{68}$ However, the attraction of Australia as a location for mining investment remained: a new chapter in the evolution of Gold Fields' interests in Australia was about to begin. 
This text is taken from Consolidated Gold Fields in Australia: The Rise and Decline of a British Mining House, 1926-1998, by Robert Porter, published 2020 by ANU Press, The Australian National University,

Canberra, Australia.

doi.org/10.22459/CGFA.2020.05 